\title{
The Origin of Theatre in the Princely State of Tripura
}

\author{
Somdev Banik \\ Tripura University, India
}

\begin{abstract}
The Kings and princes of Tripura during the $18^{\text {th }}$ and19th centuries were keen enthusiasts of art and literature. Bengali literary and artistic traditions deeply impacted the royal cultural taste, and Agartala emerged as a parallel centre of literary and cultural activities beyond Kolkata. Through royal patronage, theatre grew as a form of private entertainment. With independence, with the influx of migrants, newer groups grew rapidly bringing in new issues and styles. Theatre in Tripura finally took the form of a cultural movement during the sixties. This paper traces the growth of theatre in Tripura, which was essentially Bengali in language and spirit, during the late $19^{\text {th }}$ and early $20^{\text {th }}$ centuries till Independence.
\end{abstract}

Keywords: palace drama, royal patronage, theatre practice, stage

The Royal legacy of the kingdom of Tripura is one of the oldest in this country. Established in 1280 by Ratna Fa, this Manikya dynasty has seen a line of 185 kings ruling this state of Tripura, often referred to as Hill Tipperah by the British Indian Empire. Since a large portion of the territory of Tripura included the fertile lowlands of Bengali inhabited areas, Bengali culture and traditions had always dominated the cultural and literary firmament of this kingdom. Even the chronicle of the dynasty, Rajmala was written in Bengali verse in the fifteenth century by the court pundits Sukreshwar and Baneshwar, on the basis of recitations of the royal priest of Dharma Manikya, Durlabhendra Chantai, of an oral tradition in the Tripuri language. Bir Chandra Manikya, ruling Tripura during the second half of $19^{\text {th }}$ century, enacted several reforms and modeled his administration after the pattern of British India. Birchandra and his son Radhakishore Manikya refurbished the cultural frontier of the state, by openly patronizing Hindusthani vocal and instrumental music, Manipuri music and dance forms, Bengali folk musical and theatrical traditions, Kirtans, Pachali recitations, forms of Krishnalila narrations as well as jatra performances. Early dramatic forms emerging in Tripura were a result of the efforts taken by the princes and courtiers of the Palace in makeshift stages within the compound. As the viewership and interest increased, theatre moved out of the Palace confines to open fields, school compounds or private lawns of the aristocrats. The early performances were mostly religious, allegorical or patriotic in theme, though vulgar and lewd jatra shows for rural audiences also made their inroads during this time.

The practice and popularity of Bengali musical plays (geeti natya), paala acting and other folk dramatic forms grew in Tripura during the last few decades of $19^{\text {th }}$ and early decades of $20^{\text {th }}$ centuries. Even experimentations between different ancient and modern forms, encouraged by the ruling dynasty led to enrichment and diversification of the local theatrical traditions. Birchandra Manikya turned his palace into a centre of musical training and learning where exponents from 
different parts of India assembled and found patronage. It is his effort which saw a fusion between the Gaudiya and the Manipuri traditions resulting in a unique style of rendering Krishnalila oriented paalas. Radhakishore Manikya was as talented a connoisseur of art and culture as his father, if not more. His primary interest though was literary revival, art and culture did not suffer any neglect in his hand. He was a poet and painter himself. It's during his time that Rabindranath visited Tripura several times. Radhakishore sponsored an annual grant of Rs. 1000/- for Shantiniketan and helped Rabindranath in introducing Manipuri music and dance to the outside world. It's during his rule that two Opera styled performance companies, Kasharipatty and Acharyapara Jatraparty, in the tradition of Dhaka Barisal jatra companies grew up in Agartala. Though they were semi-professional groups, their rendering of popular religious paalas were in high demand both in rural and town areas. Inspired by their popularity, several groups of hilly people also undertook to enact Hindu religious stories in the uphill tribal areas of Tripura.

The first Westernised theatre stage grew up in Agartala during Radhakishore Manikya's reign, in 1897, known as Ujjayanta Natyasamaj. Bengal famous Star Theatre used to visit Tripura on different occasions during this period. Ujjayanta Natyasamaj based its performance practices on the style of Star theatre. This group started its journey with the performance of a five act play, Pativrata, written by Maharajkumar Mahendra Devburman, also the chief organizer of the group. This play published in 1897, is considered to be the first play written by a playwright from the state. In the reign of Maharaj Birendra Kishore Manikya, Ujjayanta Natyasamaj performed many more plays, among which were Tagore's 'Raja O Rani and 'Bisharjan'. Plays of Dwijendralal, Amritlal and Girishchandra were also enacted by this group around this time. The second original play to be written by any playwright from the state was 'Tripura Gaurav', inspired by the patriotic plays of Dwijendralal and performed by this group. All plays of Ujjayanta Natyasamaj were performed at least for a minimum of three days, the first day's show was exclusively for the royal audience, the second day's show for the women audience and the third show open for the common public.

Birendrakishore succeeded his father in 1909. Though he patronized folk forms of theatre following the footsteps of his father, his interest was in modern theatre. The proscenium theatre tradition began in the reign of Radha Kishore, but was nurtured by Birendra Kishore to its potential, while training the local artistes with the necessary skills. Birendra kishore was directly involved with Ujjayanta Natyasamaj initially, later on he formed another group called Pushpbanta Natyasamaj. Birendrakishore worked as the playwright, artist, music composer and director of this company. Some religious song dramas written by the king himself were performed with great zeal on the stage of Pushpbanta for some time. The king's keen interest in drama inspired the royal family members, the Thakur society, local artists and actors from Bengali and Manipuri community to actively engage in building an environment congenial to flourishing theatre. This led to the growth of several aristocratic amateur theatre parties in Agartala during Birendrakishore's rule. One exclusive women's theatre also came into existence under the leadership of Maharani Pravabati Devi within the palace. 1917 onwards grew up several theatre groups owned by the Thakurs like Ranbir Karta's Theatre, and amateur groups of Lebu Karta, Surendra Karta, and Narsimha Karta. These private theatre groups experimented with different forms and practices of modern theatre within their limited scope. Lebu karta alias Brajabihari Debbarma was an avid theatre enthusiast and accomplished instrumental musician in the court of Birchandra Manikya. He tirelessly experimented with newer ways of applying and integrating classical and instrumental music in musical dramas. In Lebu Karta's theatre mostly musical operas and mythical plays with rich content of songs and dance were enacted.

After Ujjayanta and Pushpbanta Natyasamaj, Ranbir Karta's theatre was the one to have contributed significantly to the evolution of theatre practice in Agartala. Ranbirkarta's theatre 
interests, acting skills and talent were honed in close proximity of Birendrakishore Manikya himself. The former constructed a stage within his house and almost for a decade continued to support stage performance with utmost dedication. Ranbir Karta's passion enthused the youth and student fraternity of Tripura and drew them to amateur acting as a mode of creative expression and social bonding. Theatre for the first time emerged out of the confines of the palace and royalty to become an art form of the middle class students and professionals. By 1923 theatre groups like Umakanta Academy Chatranatya Sangstha, Edward Memorial Medical Institute's Theatre Group, Tarun Sangha, Student's Association's Theatre Wing and Belonia Students' Theatre Sangstha made forays into the arena of modern theatre practice. In the course of time, Students Association's Theatre Wing emerged as the most successful of all these amateur groups. Umakanta Academy Natya Sangstha started regular theatre practice from 1923 under the supervision of the institute's sports teacher Sri Dinesh Chandra Chaudhuri. In 1925 it performed on the newly built stage of the school a play titled, Bhisma, which was an adaptation of the original story by Dineshbabu for the school children. In fact, Bhisma marked the beginning of school level theatre practice in Tripura. Even without any government recognition or support, Umakanta Academy Sangstha continued performances for a long time under the able guidance of several theatre enthusiast teachers of the Academy, namely Shital Chandra Chakraborty, Bhupendra Chandra Chakraborty, Satish Chandra Chakraborty, Indubikash Chaudhuri, Anil Kumar Dasgupta etc. Gradually, other schools came to follow the trend set up by Umakanta Academy, and we see schools even in small sub-divisional towns soon starting their own groups. The students' group of B.K.Institution of Belonia town was the most noteworthy of such school level drama groups. Many student activists of this period in their later life came together to set up Jogamaya Natya Samaj in Belonia to carry forward their school passion. This Jogamaya Natya Samaj made notable contribution in the thirties towards the growth of theatre culture at the subdivisional level in Tripura.

In 1926 Tripura Students Association was established in Agartala. The theatre wing of this group unleashed a new phase in the theatre history of Tripura. It brought an end to the mythical theatre tradition of Girish Ghosh era which had dominated theatre in Tripura till now and replaced it with Sisir Bhaduri's realistic dramatic tradition. Sisir Bhaduri had already captured the imagination of the Kolkata theatre goers with his modernist themes and their realistic representation on the stages. The actors of this students' group were highly motivated by the tradition of Sisir Bhaduri and adopted his thematic concerns and style to the stages of Tripura. By 1935, Tripura Students' Association was the most successful group in the theatre arena of Tripura, preparing the local stage audience for a newer and more contemporary proscenium theatre. The private stages patronized by the Royal dignitaries were already on the wane. They were gradually been replaced by economic, frugal stage set ups and props, erected through collective subscriptions and donations. This also set a new trend among the small town theatre lovers to perform plays of local writers on contemporary issues.

In 1928, Maharaja Birbikram Kishore Manikya ascended the throne and attempted to revive the court centric drama, which was very popular during his father and grandfather's times. He had already formed a theatre party 'Tripur Natya Sammilani' a few years back towards this end. He composed a few song dramas and dance dramas fusing Manipuri and Bengali dialogues and style and performed them on his stage. Among his successful plays were Chandkumudini and Sri RadhaKrishna Lilabilas. The latter play was widely appreciated when performed on the stage of Tripura House at Kolkata in 1934. Apart from his own plays, many other song dramas written by local writers were also performed on the stage within the palace. They were mostly religious in theme, with Bengali dialogues adapted to Manipuri performative practices. The first patriotic and historical play of Tripura, 'Jayabati' or 'Tripur Sati' was written and published in 1926 at the behest of Tripur Natya 
Sammilani. Through Maharaja Birbikram's generous patronage, Tripur Sammilani grew into a group of excellence with respect to stage direction, lighting and musical accompaniment. The orchestra department of the group was especially highly acclaimed. Under the stewardship of famous musician Anil Krishna Thakur, others like Bankim Bihari Debbarman, Bipin Behari Debbarman, Suresh Krishna Thakur, Hemanta Kishore Debbarma worked tirelessly to develop this field of the group. After a productive spell of seven years, this group came to its untimely demise. Several jatra teams grew up during Birbikram's tenure of which Laksminarayan Opera Party was most active and famous. Of course, these jatra parties were most active and popular in the rural areas.

The Minister in the Royal Court of Tripura, Rana Bodhjung Bahadur was an earnest theatre lover. Under his patronage and worked out by some old timers of Tripura Students' Association's Theatre Wing, a new group called Matrimandir made its appearance in 1936. This new group was more progressive in their style and expression compared to their predecessors. Their successful journey continued for the next few years. Times were fast changing and so did theatre trends. There was a need to widen the scope and gamut of theatre practice and take to the common man. In this direction, Matrimandir was revamped into Tripur Shilpayatan, under the leadership of one of the greatest theatre activists of Tripura, Tripuresh Majumder. Tripuresh Majumder's name is taken with reverence even today not just as an accomplished actor but also a great theatre organizer. This group worked hard to spread the spell of theatre to not just distant towns and villages but among the youth and adolescents. The members of this group achieved this by taking their productions to subvisional towns and inspiring or helping amateur groups by providing financial and technical support in their individual capacity.

The few years of Second World War saw a decline in productions throughout Tripura. In fact, apart from big names like Tripur Shilpayatan and Police Dramatic Club, most of the smaller groups disintegrated during this period. 1947 was a watershed in the history of Tripura, not because India won independence, but as millions of refugees from East Pakistan flooded Tripura, bringing in new actors, newer thoughts, styles and practices and burning contemporary issues to work them out on the stage. Within a few years, in Agartala and the other sub-divisional towns like Sonamura, Belonia, Udaipur, Khowai, Kailasahar, Kamalpur and Dharmanagar, amateur theatre groups grew rapidly making theatre an important medium of creative expression and popular entertainment. Most of them were aware of contemporary movement and practices prevalent in Bengal and were influenced by them. From 1948 onwards, progressive groups like Shilpi Sansad, Lokshilpi Sansad and Shilpayan entered the arena with their blend of folk, traditional and contemporary styles. The most important contribution made by Lokshilpi Sansad which emerged in 1955, was bringing in women actors to perform in female roles ushering in a new era in theatre culture of Tripura. Till that time, there was no permanent theatre stage or hall for performances and the groups had to contend themselves with make shift arrangements. From 1960 onwards, theatre had become a full fledged cultural movement in Tripura, with many groups coming forward to participate in Theatre Competitions and Festivals organized by Government Agencies and Departments throughout the state. School Level, College Level and Office Level participations became an annual affair encouraging newer groups to enter the scene.

With Independence, theatre in Tripura had finally emerged from the closets of royal patronage to the democratic and progressive frontiers of collective enterprise. From a mode of private entertainment, it evolved into a genre of popular cultural activity, provoking young and amateur writers, actors, directors and enthusiasts to experiment with existing forms of practice and blend it with modern styles and conventions to suit the needs of time. But pre-Independence theatre 
46 The Origin of Theatre in the Princely State of Tripura

in Tripura was essentially Bengali in style and language and it took another couple of decades for indigenous theatre to make its mark among the theatre lovers of Tripura.

\section{References}

Datta, Ramaprasad. (2002). Nabanatya Andolone Tripurar Lokashilpi Sansad. Tripurar Natya Andoloner Dhara, ed. Shakti Haldar. Kolkata: Debkumar Basu. pp. 48-53.

Datta, Ramaprasad. (2008). Shadhinottar Juge Tripurar Natya Andolan. Tripura Theatre. Vol-2, No.1. pp. 3341.

Haldar, Shakti. Introduction. (2002). Tripurar Natya Andoloner Dhara, ed. Shakti Haldar. Kolkata: Debkumar Basu. pp. 20-21.

Gupta, Anil Chandra. (2002). Tripuray Bangla Natyacharcha. Tripurar Natya Andoloner Dhara, ed. Shakti Haldar. Kolkata: Debkumar Basu. pp. 33-47.

Dr. Somdev Banik teaches English at Tripura University. His specialization is Postcolonial Literature. He has many articles on Culture Studies and Partition Studies. 